\title{
The Genesis of the Gecekondu: Rural Migration and Urbanization (1976)
}

Kemal H. Karpat

\section{(2) OpenEdition}

\section{Journals}

Electronic version

URL: https://journals.openedition.org/ejts/54

DOI: $10.4000 /$ ejts.54

ISSN: $1773-0546$

Publisher

EJTS

Electronic reference

Kemal H. Karpat, "The Genesis of the Gecekondu: Rural Migration and Urbanization (1976)", European Journal of Turkish Studies [Online], 1 | 2004, Online since 04 March 2015, connection on 26 May 2021. URL: http://journals.openedition.org/ejts/54 ; DOI: https://doi.org/10.4000/ejts.54 


\title{
eits.orgeurropean jounnal of turkish studies Social Sciences on Contemporary Turkey
}

Citation: Karpat, Kemal H. (2004) 'The Genesis of the Gecekondu: Rural Migration and Urbanization (1976)', European Journal of Turkish Studies, Thematic Issue №1 - Gecekondu, URL: http://www.ejts.org/document54.html

To quote a passage, use paragraph (§).

\section{The Genesis of the Gecekondu : Rural Migration and Urbanization (1976)}

\author{
Kemal H. Karpat
}

\begin{abstract}
The author of the The Gecekondu explains the reasons which drived him, in the course of his academic career, to write this book. The author gives many insights, sometimes in a personal way, to understand the place of this book, both in his own cursus and in the field of urban studies. He explicites his interest in migration as a factor of changes in the social structure and modernization process in the late Ottoman and Republican Turkey. Confronted to multiple difficulties in finding adequate data, he turned to more contempory and empirical subjects, providing insights about his method as well. He finally analyses the 'impact' of the book, which has contributed to initiate the development of gecekondu studies in the late 1980's.
\end{abstract}


Citation: Karpat, Kemal H. (2004) 'The Genesis of the Gecekondu: Rural Migration and Urbanization (1976)', European Journal of Turkish Studies, Thematic Issue $\mathrm{N}^{\circ} 1$ - Gecekondu, URL: http://www.ejts.org/document54.html

To quote a passage, use paragraph (§).

\section{Introduction: The Roots of the Interest in Migration}

The book published in 1976 represents the second phase of my long-range interest in population movements, as a key force in the social and political transformation of Turkey and other countries. The initial interest which began as an impressionistic reaction to an actual case of migration, eventually evolved into a systematic effort to assess empirically and conceptually the process of migration not merely as one of human dislocation but as a substantial force of urban and rural change and renewal.

[2] The first phase of this interest was a personal, powerful experience in my early youth when I witnessed the abrupt departure of most of my relatives and friends from Dobruja to Turkey. I was haunted by the empty houses and the howling dogs that after following the migrants' caravan, returned to their masters' empty houses to die of grief. The sudden silence of the streets on which emigrants' children had played and many other disheartening events created in me both a revulsion and curiosity towards migration. The revulsion was a subconscious reaction against the forces that had compelled my departing relatives and friends to leave their homes and a way of life that I had thought was permanent and unchangeable. The curiosity about migration was rather imperceptible at the beginning but grew stronger after I realized the complexity of the process and it effects.

[3] From the outset, everybody knew that the departing migrants were young and relatively poor but dreamed of receiving the land, houses, oxen, etc. supposedly promised by Mustafa Kemal (Atatürk) if they settled in Turkey under a series of migration agreements Turkey had signed with the governments of Romania and Bulgaria in the 1930s. Years later when I also had to migrate to Turkey, I visited many relatives settled in Central Anatolian, Aegean and Thracian villages whose land, climate, and work conditions seemed to be worse than those in the 'memleket' as they fondly referred to their old village in Dobruja. (Torn by nostalgia many embraced me in order to 'memleket kokusunu alayım' to inhale the scent of the old country which as a latecomer I presumably retained.) 
Citation: Karpat, Kemal H. (2004) 'The Genesis of the Gecekondu: Rural Migration and Urbanization (1976)', European Journal of Turkish Studies, Thematic Issue $\mathrm{N}^{\circ} 1$ - Gecekondu, URL: http://www.ejts.org/document54.html

To quote a passage, use paragraph (§).

[4] For my part, I was struck by the profound behavioral changes my immigrant relatives had undergone. Conscious of their not-so-flattering status as 'muhacir,' they were struggling to climb the social ladder by accumulating wealth, changing occupations and seeking to resettle in more prosperous areas. Some had already moved to towns and cities as had many of the long established villagers of Anatolia and members of the settled nomadic tribes of Turkmen and Kurds. The push factor behind the urge to move to the city was the dire poverty prevailing in most Turkish villages as a result of overpopulation, lack of arable land, low crop yields, and high taxation.

[5] My early personal encounter with migration, outlined above, acquired a historical dimension in the late 1950s and early 1960s as I undertook extensive research in some twenty provinces of Turkey in order to select three or four prototype vilayets for a study of the social roots of the Turkish political system, which I had analyzed at the national level in Turkey's Politics (1959). The research alerted me first to the seminal role the provincial elites played in Ottoman history and in the national life of Republican Turkey, despite overcentralization, bureaucratic domination and lack of official recognition. Consequently, I chose the provinces of Balıkesir, Erzurum and Gaziantep and conducted rather extensive work there. Balıkesir (Karesi) contained a large number of immigrants from Crimea, Caucasus and the Balkans, while Gaziantep harbored both numerous settled Turkmen tribes and a variety of deep-rooted elites but relatively few immigrants from abroad. Erzurum, on the other hand, seemed to have maintained a high degree of social and cultural continuity as well as local consciousness and pride in its past.

[6] I accumulated considerable material in Gaziantep but did not publish any of it. Although an editorial in the local newspaper (apparently written in consultation with a local son in a high position in Ankara) 1 warned me that 'the time to study the society and history of Antep

1 This gentleman apparently became afraid that his family name might be spoiled when he learned that I had had a long talk with a man who had been the vali of Cilicia under French occupation in 1921. My informant claimed that before he was pardoned and returned from Syria to his native city he had worked as an agent of the Turkish government there. On historical Gaziantep (Aintab), see Leslie Peirce (2003). The book contains the records by the kadı court in 1540-41. Also see S. Hülya Canbakal (1999). 
Citation: Karpat, Kemal H. (2004) 'The Genesis of the Gecekondu: Rural Migration and Urbanization (1976)', European Journal of Turkish Studies, Thematic Issue $\mathrm{N}^{\circ} 1$ - Gecekondu, URL: http://www.ejts.org/document54.html

To quote a passage, use paragraph (§).

has not arrived,' my book was delayed by an important discovery that the contemporary Turkish political system should be studied together with its social, historical roots. Despite the claims of the republican leaders that they had created a new state and society, they had changed only the political regime. In reality, they largely retained the center's old collaboration with local notables including rich landlords, merchants, intellectuals, and those members of the ulema who showed allegiance to the Republic. The bond of hemşerilik, rooted in belonging to the same town, area and class, was a powerful tie that the central authority had to respect. Paradoxically, what sustained the social and historical continuity at the local level and the pervasive political influence of the traditional local elites - 'all politics is local', as an American politician put it -- was an ongoing process of social mobility, change and renewal. The element of social and cultural continuity would be obvious to any trained eye, but the underlying change and renewal were far more subtle and intricate and migration played a key role in fueling them.

[7] Throughout Ottoman history the countryside elites moved to the provincial towns either by acquiring government positions or by becoming the allies of the central government against the established urban elites. Upon acquiring power and wealth they brought their kin to the city. The formation of these regional elites in the provincial towns accelerated in the sixteenth century after they became instrumental in the collection of taxes and so gained increasing control and influence in the community. Historically, the central government used economic, social, and symbolic means to legitimize the rise of both the regional elites and new local elites to replace them back in the countryside (Piterberg 1990: 275-89).

[8] Eventually, many former members of the local elites joined the central government and settled in the capital, bringing along their families and their own close ties to their original country, locality and community. The migration to Istanbul of relatives of the high dignitaries was illustrated even during the devşirme period, when Grand Vizir Mehmet Sokollu (Sokolovich) (1505-79) brought to Istanbul dozens of his Slavic relatives as had his predecessors, the Grand Vizir Rustem paşa (Okupovich) and the husband of Sultan Süleyman's daughter, Mirimah (Samarcic 1996: 32, 71-83). In fact, throughout Ottoman history there was a steady migration of local and regional elites and their relatives and friends 
Citation: Karpat, Kemal H. (2004) 'The Genesis of the Gecekondu: Rural Migration and Urbanization (1976)', European Journal of Turkish Studies, Thematic Issue №1 - Gecekondu, URL: http://www.ejts.org/document54.html

To quote a passage, use paragraph (§).

to Istanbul. Initially slow, the migration and urbanization of the elites and social mobility in general accelerated in intensity and scope during the nineteenth century after millions of Muslim subjects immigrated and settled on lands still under the sultan's rule.

[9] The seriye sicilleri of Antep, one of the most complete and best preserved in Turkey, recorded a continuous inflow of countryside people into the city. Some joined the ruling strata either in cooperation with or defiance of the central government, but many remained destitute and ready to move elsewhere. An infusion of the culture of the rural tribal people into that of the 'upper' urban stratum accompanied the social influx.

[10] Ultimately I became convinced that Ottoman modernization could be understood only through a close, inside examination of the changes in the Ottoman and Turkish social structure and that migration was a key to those changes. One of the chief forces behind the two-hundred-year transformation of the late Ottoman state and modern Turkey, migration made old social structures and cultural systems into new ones and, at the individual level, produced corresponding changes of identities.

[11] I, therefore, decided to engage in a macrostudy of the role of migration in the last Ottoman century. The major first handicap was a lack of information. Although from 1812 onward the Ottoman state and the Republic have faced a constant tide of immigration (most recently represented by the migration from Bulgaria between 1985 and 1989) (Karpat 1989) the abundance of material on migration in Turkish and British archives remained untouched. The lack of published information was compounded by conceptual and methodological shortcomings. Migration in the context of Ottoman and Republican history was regarded as a consequence of political forces rather than as an independent factor capable of effecting long range political, social and cultural changes. Yet, my early encounters with migration as mentioned, impressed me that the event had a wide transforming effect. In this regard, the 
Citation: Karpat, Kemal H. (2004) 'The Genesis of the Gecekondu: Rural Migration and Urbanization (1976)', European Journal of Turkish Studies, Thematic Issue $\mathrm{N}^{\circ} 1$ - Gecekondu, URL: http://www.ejts.org/document54.html

To quote a passage, use paragraph (§).

existing western literature on migration helped define certain of its aspects but left unanswered many specific questions concerning Ottoman-Turkish migration².

[12] It is clear that each migration has a context of its own defined by the history, experience and normative rules of the society in which it takes place. One cannot study migration in Muslim lands by ignoring the Koranic tenets on the subject, the Muslim calendar, which begins with an act of migration, and the fact that Prophet Mohammad himself was a migrant in Medina. The Koranic obligation of the receiving community to help settle the migrants and accept them as brothers played a crucial role in the assimilation of the immigrants in the Ottoman state and Republican Turkey33.

[13] I concluded that a proper understanding of the place and transforming role of migration in the Ottoman state and the Republic demanded not only a mastery of the relevant information, but equally important, direct observation of the phenomenon itself. In other words, I believed that a study of the contemporary migration would facilitate the understanding of the historical ones as far as their transformational effect on the individual migrant and the rural and urban space was concerned. Consequently, I decided to acquaint myself personally and directly with the minutest details of the causes, phases and especially the transforming effects of the migration that was taking place in Turkey in the 1960s and 1970s.

[14] In sum, the Gecekondu study was planned as a broad multi-sided project for two equally important reasons: to understand the cause and impact of the current village-city migration in contemporary Turkey and to use the knowledge and insights thus acquired to fathom the transforming effects of the historical migrations on the Ottoman Empire. The extraordinarily large number of villagers moving to the city and the rise of immigrant

2 My writings on migration have been translated into Turkish and artfully put together and published by the Tarih Vakfı. The publication includes a lengthy, previously unpublished, introduction and a discussion of the reliability of Ottoman statistics and mentions a variety of general works on migration (Karpat 2003).

3 I studied the role of migration in the transformation of the Ottoman state in a recent work. It became evident during the lengthy research on this book that although migration is a powerful force for change, its transformational effect is dependent on other economic, cultural, ideological, political, etc. forces which can give it direction and intensity (Karpat 2001). 
Citation: Karpat, Kemal H. (2004) 'The Genesis of the Gecekondu: Rural Migration and Urbanization (1976)', European Journal of Turkish Studies, Thematic Issue $\mathrm{N}^{\circ} 1$ - Gecekondu, URL: http://www.ejts.org/document54.html

To quote a passage, use paragraph (§).

settlements, the gecekondus, on the outskirts of Istanbul and other Turkish cities supplied the necessary material for the study.

[15] I was fortunate to receive funding from the Department of Social Studies of the Middle East Technical University in Ankara where I regularly taught one semester per year from 1968 to 1971, when the president installed after the military coup of 1971 annulled my contract. (In those days mere interest in the gecekondu was deemed proof of leftist subversion and apparently still is for Professor Engin Akarlı, who was my assistant and head of the research team, had to resign his position at Boğaziçi University and remains barred from the Başbakanlık Archives.)

[16] I regarded the village to city migration as a seminal development that could change the social and cultural arrangement of Turkey as well as its political structure, including voting patterns and party alignments. Although the original two-party (CHP-DP) system was preserved, the parties' ideological orientation underwent subtle modifications. The DP (Democrat Party) was closed but reemerged under new names, such as Adalet, Yeni Türkiye, Anavatan and Doğru Yol, while the CHP remained the bulwark of the old elitist-republicans until 1980. Votes from the gecekondu played a decisive role in determining the outcome of urban elections. The gecekondus we studied voted 61 percent for DP, 25 percent for CHP (Alevis favored CHP as did their villages). The Marxist TIP (Labor Party) received 9 percent, while a religious party received just 3 percent.

[17] The immigrant communities could produce militant supporters for the extremist factions, but the prevailing culture and attitudes in the gecekondu favored the status quo, which could be manipulated to satisfy the gecekondu dwellers' demands. Indeed, contrary to many expectations, the gecekondu dwellers were generally conservative; only certain areas were dominated by radicals of the left or right 4 . The dwellers' chief demand was the legalization of the land plot on which each dwelling had been built and they realized that the

4 I visited in a village in the Sebinkarahisar region the father of a well-known leftist militant in a gecekondu of Istanbul. The father, a peaceful religious man, believed that the 'wicked' city had undermined his son's upbringing as a 'good Muslim and honest fellow.' For politics in the gecekondus see Karpat (1975). 
Citation: Karpat, Kemal H. (2004) 'The Genesis of the Gecekondu: Rural Migration and Urbanization (1976)', European Journal of Turkish Studies, Thematic Issue $\mathrm{N}^{\circ} 1$ - Gecekondu, URL: http://www.ejts.org/document54.html

To quote a passage, use paragraph (§).

granting of the land deed could be achieved by supporting the political party that promised it. The Anavatan Party of Turgut Özal made that promise and won the elections of 1983.

\section{The Approach and Scope of the Gecekondu Study}

[18] The research for the Gecekondu study, while maintaining my broad interest in historical migrations, concentrated exclusively on contemporary village-to-city migrations. It had three specific immediate goals. The first was to determine both the reasons, push factors, for migration in the villages and the pull forces at the destination in the cities. The second goal was to determine how and why the villagers chose a particular city and quarter within it and how they formed the financial, legal, technical, social and administrative relationships accompanying the building of the dwelling, the gecekondu. The last goal was to determine the changes in the occupation, personality, habits, mode of life and political orientation of the villagers who had turned overnight into quasi-urban dwellers. As part of this third goal the research paid special attention to the migrants' relations with and modernizing impact on their original villages and on the city and vice versa.

[19] Three research teams of two or three members each spent considerable time in the immigrants' original villages in northeastern Turkey. They studied the factors that forced the villagers to migrate to cities as well as their impact on their original homes. I personally conducted interviews in about a dozen villages in the provinces of Giresun and Sivas. A comprehensive questionnaire addressed itself to all the basic questions, and the answers received are detailed in the published work. Although the impact of the immigrants both on their original villages and on the city could have been given fuller treatment, I subsequently have dealt with the upward percolations of the folk culture, cuisine and linguistic terms into the urban national culture 5 . I once thought that the cultural phenomenon I was witnessing consisted of the fusion of the folk culture into the urban one, but I now realize the phenomenon was an unprecedented dialectical process that still is producing a truly national Turkish culture. 
Citation: Karpat, Kemal H. (2004) 'The Genesis of the Gecekondu: Rural Migration and Urbanization (1976)', European Journal of Turkish Studies, Thematic Issue $\mathrm{N}^{\circ} 1$ - Gecekondu, URL: http://www.ejts.org/document54.html

To quote a passage, use paragraph (§).

In other words, it is a type of cultural, political and religious homogenization through which the local and urban cultures are interacting to produce a comprehensive national culture. The issue cannot be given further analysis here despite its vital importance ${ }^{6}$. Suffice it to say that Islam played an essential role as the main instrument of consensus while itself acquiring new 'national' characteristics. Thus can be claimed that the worldly, multidimensional and moderate Islam that emerged in Turkey during the past thirty years was brought to the cities and nationalized by immigrants, many of whom were followers of the Sufi popular orders ${ }^{7}$.

\section{The Term Gecekondu}

[20] The term gecekondu used as the main title of the book has a narrow scope that does not reflect the wide scope of the migration process. Coined by city residents, the term reflected almost exclusively their negative reaction to the influx of the villagers who defied established urban norms. It is in essence a legal definition that describes a makeshift, uncomfortable hut erected overnight on land owned by the state, municipality or individuals in defiance of the building codes and property rights. The definition is limited strictly to the urban space and the building itself and disregards entirely the complex human factors of which the dwelling is just a symptom.

[21] The three gecekondu settlements of Nafi Baba-Hisarustu, Balta Liman and Resit paşa that we studied contained a fairly large number of Alevis. The third one also harbored a number of Kurds. In all three, the Sunni-Alevi differences appeared to be secondary to the

6 I dealt with these points in a communication submitted to a conference attended by leading Turkish historians and social scientists held at Yıldız Technical University on November 2, 2002. My paper outlines the philosophy approach and methodology of the Center for New Research being established at Yıldız Technical University of Istanbul.

7 The immigrants from the Caucasus played an important role in disseminating and popularizing the Nakshbandia-Khalidiya order in Anatolia. The membership in the order brought together the immigrants and natives and forestalled many conflicts. The Ottoman government became so alarmed by the growing power of the popular Nakshbandia that in the 1880s it ordered the arrest and exile of Sheyh Ahmet of Sivrihisar - originally from Daghestan although the Sheyh was loyal to the government and the caliph. Kiamil paşa, then prime minister, advised Sultan Abdul Hamid II that a man who in three years gathered such a broad following could become dangerous. See Karpat, The Politicization of Islam..., pp. 111-112. 
Citation: Karpat, Kemal H. (2004) 'The Genesis of the Gecekondu: Rural Migration and Urbanization (1976)', European Journal of Turkish Studies, Thematic Issue $\mathrm{N}^{\circ} 1$ - Gecekondu, URL: http://www.ejts.org/document54.html

To quote a passage, use paragraph (§).

shared common status as 'gecekonducu,' or 'us' versus the 'them,' 'şehirler'of the established city population. One may rightly say that the desire of the gecekonducus to achieve success contributed to the growing spirit of entrepreneurship in Turkey. The gecekonducus we interviewed in the 1960s and thereafter regarded the life in the gecekondu as a temporary provisional, rather than permanent, way of life. Yet the us and them dichotomy seemed to express cultural and social rather that political differences. In several ways the gecekondu regarded the old city residents' way of life as their own ultimate goal, even as an ideal model. To obtain it, the "gecekonducus" sought de jure ownership of the land on which the gecekondu was built, regular predictable employment, and opportunities for successful entrepreneurship.

[22] At the time of our study Islamic fundamentalism apparently had made little headway in the gecekondu although the imams and hojas were highly respected as sources of advice and guardians of traditional values as well as performers of religious rites. The imams' influence and following actually were far less than in the villages of origin, and the immigrants' sense of Islamic identity seemed to be becoming more rational, selective and attuned to the social and political realities of Turkey. At the same time, I believe, the immigrants' view of their membership in the political community and their growing awareness of their rights as citizens and the power of the ballot, which existed in the limited form in the village, acquired new strength and dimension in the gecekondu. In this context, Islam in the gecekondu mediated and harmonized the two existences of old villager and new urbanite now embedded in the shanty dweller and thus changed and strengthened itself not so much as code of behavior but an instrument of introspection.

[23] The Alevis provide a good example of the process. An Alevi village leader or pir, who had just returned from pilgrimage to Kerbala proudly showed me pictures of Ali and Hüseyin but expressed no interest in leading an Alevi revival in Turkey. His relatives and followers who had emigrated to the gecekondu, on the other hand, had decided that Haci Bektaş was their luminary and organized special trips to his tomb and festivities during the month of Muharrem. Although awakened to their Alevi identity and seeking respect for it, they 
Citation: Karpat, Kemal H. (2004) 'The Genesis of the Gecekondu: Rural Migration and Urbanization (1976)', European Journal of Turkish Studies, Thematic Issue $\mathrm{N}^{\circ} 1$ - Gecekondu, URL: http://www.ejts.org/document54.html

To quote a passage, use paragraph (§).

lived peacefully with their Sunni neighbors and at that time did not demand recognition as a distinct religious group.

[24] The term gecekondu represented the city's traditional sense of superiority towards the village and the urbanites' alarm that peasants aspired to share the civilization and benefits of the city life, and possibly then to claim to be their equals. In the end, this is exactly what came to pass in politics, education and living standards without causing the collapse of the social order.

[25] Despite all the limitations embodied in the term gecekondu, however, I decided it aptly reflected the specific 'national' view, cultural biases and reaction of the Turks towards a process that was changing their lives. The village-to-city migration was endemic throughout the developing world but in each country it - or an aspect of the movement - acquired a specific name such as barrio (Argentina) favela (Brazil), bidonville (French Africa) or busti (India), expressing the national view or image of it. This is why the first chapter of the book is dedicated to a comparative study of the gecekondu as a global phenomenon, which in each country takes on its own 'national' peculiarities, as reflected in its name. Years after conducting my research in Turkey, I had the chance to visit two or three favelas in Rio de Janeiro, which were dominated by dangerous gangs in contrast to the safe and subdued Turkish gecekondus. Different from the Turkish gecekondus adherence to one faith (Islam) the Brazilian favelas practiced various African religions as I witnessed in Rio.

[26] At present, I agree, the village migration and the gecekondu have evolved into something new and different, making the term obsolete. Yet it would be very difficult to replace the original 'gecekondu,' which appeared more or less spontaneously in the late 1960s and was popularized overnight. Although gecekondus seem to have been risen periodically in Turkish cities throughout the Ottoman era, the term belongs specifically to the village-to-city migration in the Republic after the 1960s. It defines a turning point in the Turkish history, the gecekondu phase of Turkish urbanization-modernization, the initial gigantic step of Turkish villagers coming into the age. 
Citation: Karpat, Kemal H. (2004) 'The Genesis of the Gecekondu: Rural Migration and Urbanization (1976)', European Journal of Turkish Studies, Thematic Issue $\mathrm{N}^{\circ} 1$ - Gecekondu, URL: http://www.ejts.org/document54.html

To quote a passage, use paragraph (§).

\section{The Impact of the Gecekondu Book}

[27] The response to the book's publication was positive in the West, as indicated by various reviews, but in Turkey the reaction was muted for several reasons. The book, written in English, was not translated into Turkish until twenty-seven years after its publication, a delay caused by Turkish readers' disinterest in the topic itself and in the book's broad view of migration ${ }^{8}$. Indeed, migration and village studies have been until recently the stepchild of social studies in Turkey despite their seminal importance for understanding the evolution of Ottoman society and the rise of contemporary Turkey. The historical settlement of tribes and of Turks in Anatolia and the Balkans have been largely unstudied apart from works by Cengiz Orhonlu and Ö. Lutfi Barkan and Tayyıp Gökbilgin. Even the massive migrations and the settlement of the Crimean, Balkan and Caucasian migrants in the nineteenth century are still awaiting detailed research and analysis, as the volumes of Bilal Şimşir on the Balkan migration consist mainly of reports from the British consuls stationed in a few cities in today's Bulgaria. Meanwhile, a quick glace at the gecekondu bibliography compiled by the publishers of the European Journal of Turkish Studies indicates that the majority of works have been published since 1980.

[28] The lack of interest in migration, village studies and social studies in general derived directly from the elitist nature of the Turkish political-educational system and the mercantilist view that the value of higher education is in its pecuniary yield. Engineering, medicine and law, attracted a large number of bright students, but the social sciences were marginalized as the 'useless' hobbies of a few subversives9. Until recently, a 'leftist' was anyone questioning the social order. So, it took the leftist and Marxist upsurge of the 1960s and 1970 s to give sociology and the other social sciences a degree of respectability.

8 The Turkish publisher of the translated book proposed to use a different title for the original gecekondu which had lost its original significance and meaning. It bears the more appropriate title Türkiye'de Toplumsal Dönüşüm, Ankara, 2003.

9 For instance, the authors of earlier village studies such as Hüseyin Avni, İsmail Hakkı Tonguç, Ibrahim Yasa, etc. were regarded as 'leftists'. 
Citation: Karpat, Kemal H. (2004) 'The Genesis of the Gecekondu: Rural Migration and Urbanization (1976)', European Journal of Turkish Studies, Thematic Issue №1 - Gecekondu, URL: http://www.ejts.org/document54.html

To quote a passage, use paragraph (§).

[29] Consequently the Gecekondu study presented a more progressive view of the village-to-city migration than most of Turkish academia was prepared to accept in the 1960s when the village migrations were regarded as an invasion threatening the city and its way of life. No doubt, the same prevailing attitude had influenced previous studies on immigrants and The Gecekondu. The works by Oğuz Arı, Ibrahim Yasa, F. Yavuz and R. Keles appear intended to reassure the established urbanites that the migrants were capable of adapting themselves to city life.

[30] I need to repeat that the Gecekondu study was undertaken primarily to gain insight into the migration phenomenon and only secondarily to provide information for the public or a blueprint for government policy. An intellectual effort undertaken for the sake of knowledge, it should be viewed as such. A number of articles and books on Turkey in general and migration in particular have used it extensively, and most have cited it scrupulously.

\section{Conclusion}

[31] The Gecekondu book deals with the initial phase of its subject, that is, with the genesis of the village-to-city migration, roughly from 1960 to 1980. It marks a given stage in Turkey's social transformation and modernization. The study regarded the migration to the city and the gecekondu as a short, transitional phase in the villagers' journey towards urbanity. In this sense, it likewise regarded the migrants' makeshift hut as a temporary shelter, which they soon would turn into a regular urban dwelling if title to the land was secured and the national economy continued to expand. As this scenario is exactly what happened, mainly after 1983, a large part of the gecekondus became regular city quarters, although a few preserved their drab view and the gecekondu mafias emerged.

[32] Today, the village-to-city migration has changed so drastically as to have little resemblance to the village exodus of the 1960s and 1970s. The same is true for the gecekondu, which has very little in common with the enduring shantytowns of Africa, Latin America and parts of Asia. How Turkey prevented the gecekondu from becoming a permanent 
Citation: Karpat, Kemal H. (2004) 'The Genesis of the Gecekondu: Rural Migration and Urbanization (1976)', European Journal of Turkish Studies, Thematic Issue $\mathrm{N}^{\circ} 1$ - Gecekondu, URL: http://www.ejts.org/document54.html

To quote a passage, use paragraph (§).

blight on its urban landscape is a subject of vital interest. In any case, the old gecekondu era in Turkey is over. A new era of village-to-city migration and urban dwelling construction since the mid-1980s should be regarded, researched and named even as the rural to urban movement now seems ready to reverse its flow. 
Citation: Karpat, Kemal H. (2004) 'The Genesis of the Gecekondu: Rural Migration and Urbanization (1976)',

European Journal of Turkish Studies, Thematic Issue $\mathrm{N}^{\circ} 1$ - Gecekondu, URL: http://www.ejts.org/document54.html

To quote a passage, use paragraph (§).

\section{References}

Canbakal, S. Hülya (1999) Ayntab at the End of the Seventeenth Century: A Study of Notables and Urban Politics, Ph.D. dissertation, Harvard University.

Karpat, Kemal H. (ed.) (1989) The Turks of Bulgaria: The Fate of a Minority, Madison.

Karpat, Kemal H. (2003)Osmanlı Nufusu 1830-1914, Istanbul.

Karpat, Kemal H. (2001) The Politicization of Islam: Reconstructing Identity, State, Faith and Community in the Late Ottoman State, Oxford.

Karpat, Kemal H. (1975) 'The Politics of Transition: Political Attitudes and Party Affiliation in Turkish Gecekondu,' in Akarlı, E.D., and Bendor, G. (eds) (1975) Political Participation in Turkey: Historical Background and Present Problems, Istanbul.

Karpat, Kemal H. (1973) Gecekondu Sorunu Üzerine, Ankara, ODTÜ, Mimarlık Fakültesi, No.1.

Peirce, Leslie (2003) Morality Tales: Law and Gender in the Ottoman Court of Aintab, Berkeley.

Piterberg, Gabriel (1990) 'The Formation of an Ottoman Egyptian Elite in the 18 ${ }^{\text {th }}$ Century,' International Journal of Middle East Studies 22:3, pp.275-89.

Samarcic, Radovan (1996) Sokollu Mehmed Paşa, trans M. Gaspıralı, Istanbul. 